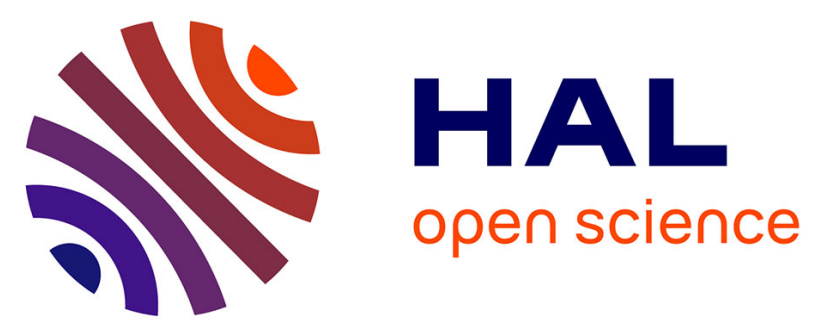

\title{
First records of the subfamilies Bethylinae (Hymenoptera: Bethylidae) and Cleptinae (Hymenoptera: Chrysididae) in Upper Cretaceous amber from France
}

Pierre F.D. Cockx, Ryan C. Mckellar, Vincent Perrichot

\section{To cite this version:}

Pierre F.D. Cockx, Ryan C. Mckellar, Vincent Perrichot. First records of the subfamilies Bethylinae (Hymenoptera: Bethylidae) and Cleptinae (Hymenoptera: Chrysididae) in Upper Cretaceous amber from France. Cretaceous Research, 2016, 68, pp.1-8. 10.1016/j.cretres.2016.07.008 . insu-01347739

\section{HAL Id: insu-01347739 \\ https://hal-insu.archives-ouvertes.fr/insu-01347739}

Submitted on 22 Aug 2016

HAL is a multi-disciplinary open access archive for the deposit and dissemination of scientific research documents, whether they are published or not. The documents may come from teaching and research institutions in France or abroad, or from public or private research centers.
L'archive ouverte pluridisciplinaire HAL, est destinée au dépôt et à la diffusion de documents scientifiques de niveau recherche, publiés ou non, émanant des établissements d'enseignement et de recherche français ou étrangers, des laboratoires publics ou privés. 


\section{Accepted Manuscript}

First records of the subfamilies Bethylinae (Hymenoptera: Bethylidae) and Cleptinae

(Hymenoptera: Chrysididae) in Upper Cretaceous amber from France

Pierre F.D. Cockx, Ryan C. McKellar, Vincent Perrichot

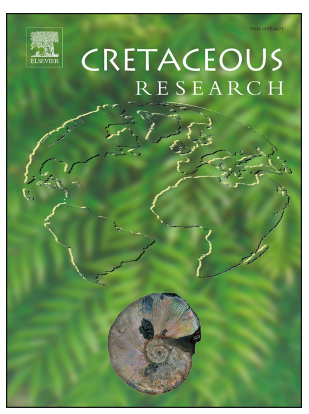

PII:

S0195-6671(16)30149-5

DOI:

10.1016/j.cretres.2016.07.008

Reference: YCRES 3429

To appear in: Cretaceous Research

Received Date: 17 May 2016

Revised Date: 5 July 2016

Accepted Date: 19 July 2016

Please cite this article as: Cockx, P.F.D., McKellar, R.C., Perrichot, V., First records of the subfamilies Bethylinae (Hymenoptera: Bethylidae) and Cleptinae (Hymenoptera: Chrysididae) in Upper Cretaceous amber from France, Cretaceous Research (2016), doi: 10.1016/j.cretres.2016.07.008.

This is a PDF file of an unedited manuscript that has been accepted for publication. As a service to our customers we are providing this early version of the manuscript. The manuscript will undergo copyediting, typesetting, and review of the resulting proof before it is published in its final form. Please note that during the production process errors may be discovered which could affect the content, and all legal disclaimers that apply to the journal pertain. 
First records of the subfamilies Bethylinae (Hymenoptera: Bethylidae) and Cleptinae (Hymenoptera: Chrysididae) in Upper Cretaceous amber from France

Pierre F. D. Cockx ${ }^{\mathrm{a}}$, Ryan C. McKellar ${ }^{\mathrm{b}, \mathrm{c}^{*}}$, Vincent Perrichot ${ }^{\mathrm{a}}$

${ }^{\mathrm{a} C N R S}$ UMR 6118 Géosciences \& OSUR, Université de Rennes 1, Campus de Beaulieu bât. 15, 263 avenue du Général Leclerc, 35042 Rennes cedex, France.

${ }^{\mathrm{b}}$ Royal Saskatchewan Museum, 2445 Albert St., Regina, SK S4P 4W7, Canada.

${ }^{\mathrm{c}}$ Biology Department, University of Regina, Regina, SK, S4S 0A2, Canada

*Corresponding author.

E-mail address: ryan.mckellar@gov.sk.ca 


\begin{abstract}
Two new genera and species of fossil chrysidoid wasps belonging to the families Chrysididae and Bethylidae are described from Charentese (Fouras Bois-Vert and Archingeay) lower Upper Cretaceous amber of France. New taxa include: Sphaerocleptes neraudeaui n. gen. et sp., and Nucifrangibulum carentonensis $\mathrm{n}$. gen. et sp. A new bethylid wasp is also described but left in open nomenclature. These findings are the first records of the subfamilies Cleptinae and Bethylinae in these deposits and time interval. The implications of these discoveries, and the features shared with previously known taxa are discussed.
\end{abstract}

Key words: Chrysidoidea; Cenomanian; taxonomy; Bethylinae; Cleptinae. 


\section{Introduction}

The family Chrysididae is relatively diverse and comprises approximately 3,000 modern species. Their distribution is cosmopolitan but shows a maximum of diversity in temperate deserts (Finnamore and Brothers, 1993). These wasps are known to be parasites or kleptoparasites of lepidopterans, phasmatodeans, symphytans, vespids and apoids (Kimsey and Bohart, 1991). The Cretaceous fossil record for this group is very partial, there are only a few taxa described: two species by Evans (1973) from Taimyr (Siberian) amber (one of them was redescribed by Krombein, 1986), one new genus and species from the Transbaikalia by Rasnitsyn (1990), and three species from Canadian amber (Evans, 1969; McKellar and Engel, 2014). In addition, a few undescribed specimens were reported from Spain (Martínez-Delclòs et al., 1999; Peñalver and Delclòs, 2010), Lebanon (Poinar and Milki, 2001) and the USA. Rasnitsyn et al. (2016) kept a record of the number of Chrysididae found in various deposits in the world throughout the Cretaceous. The Cenozoic fossil record is also sparse, with only a few species described from Eocene Baltic amber (e.g. Krombein, 1986), three from the Ukrainian Eocene Rovno amber (Perkovsky and Rasnitsyn, 2013) and one from the Dominican amber (Engel, 2006). Two species have also been described based on compression fossils from Florissant, Colorado, USA (Cockerell, 1907) and one from Oligocene of Brunstatt, France (Förster, 1891).

The parasitoid family Bethylidae is also diverse in modern settings, with 2,481 extant species and 102 genera occupying a cosmopolitan distribution but concentrated in the tropics (Alencar and Azevedo, 2013). Modern species use a sting to paralyze their prey, and host taxa consist of larvae of Coleoptera, Lepidoptera and rarely Hymenoptera. According to studies based on molecular (Carr et al., 2010) and morphological characters (Brothers and Carpenter, 1993), 
this family is the monophyletic sister group to Chrysididae. Although they are not frequent in the fossil record, the Bethylidae are known from a range of deposits and ages. Specimens have been identified in Lower Cretaceous Charentese amber, France (Perrichot et al., 2010) and Upper Cretaceous New Jersey amber, USA (Grimaldi and Nascimbene 2010). Species have been described from the Lower Cretaceous amber of Myanmar (Cockerell 1917a, b; Ross et al., 2010), Lebanon (Azevedo and Azar, 2012; Engel et al., 2016), and Spain (Ortega-Blanco and Engel, 2013), as well as from Upper Cretaceous ambers of Siberia (Evans, 1973; Rasnitsyn, 1990) and Canada (McKellar and Engel, 2014). The family is also known from Cenozoic deposits, such as the Eocene, Baltic, Oise and Rovno ambers (e.g. Brues, 1933, De Ploëg and Nel, 2004; Perrichot and Nel, 2008; Barbosa et al., 2013; Ramos et al., 2014), the Eocene Chinese amber (Hong, 2002), Oligocene Mexican amber, and Miocene Dominican amber (Sorg, 1988; Terayama, 2004). Some compressions also contribute to the fossil record of this family.

Herein, we describe new species and genera of chrysidoid wasps from the subfamilies Cleptinae (family Chrysididae) and Bethylinae (family Bethylidae). The specimens come from the lower Upper Cretaceous Charentese amber. Two samples (IGR.FRS-7.28 and IGR.FRS-7.34) originate from Fouras (Charente-Maritime, southwestern France; Fig. 1A). These amber deposits, from the lower Cenomanian sub-unit B2ms (Fig. 1B), are present in fossil wood deposits accumulated in the form of two lenses on the tidal flat. The first is primarily composed of lignite and contains pluridecimetric fragments. Their preservation suggests a low transport from the botanical source. The study of these wood fragments under SEM identified four taxa: Agathoxylon (the most abundant, 50\% of the samples), Podocarpoxylon, Brachyoxylon, and Ginkgoxylon (identified with a single sample) (Néraudeau et al., 2003). The second lens contains smaller fragments, centimetric to decimetric in size. This difference of element sizes could be 
explained by sorting due to different current speeds during deposition. Thus, the second lens is thought to be associated with an estuary setting that is less energetic.

The other specimen (IGR.ARC-419.1) described in this paper is from the uppermost of two amber strata that have been exposed in the Font-de-Benon quarry between Archingeay and Les Nouillers (Charente-Maritime, southwestern France; Fig. 1A). Contrary to the amber of the lowermost stratum (sub-unit A1sl-A, uppermost Albian) which provides an abundant fauna (Néraudeau et al., 2002; Perrichot et al., 2010), that of the uppermost stratum (sub-unit A2sm1-2, lowermost Cenomanian; Fig. 1B) contains only a few inclusions of fossil arthropods. Amber from the sub-unit A2sm1-2 is found in a clay lens with abundant botanical remains, mostly of conifers (Frenelopsis, Glenrosa, cf. Brachyphyllum, and Nehvizdya) and also with rare angiosperms (cf. Myrtophyllum), that accumulated in a mangrove-like brackish environment (Gomez et al., 2008).

\section{Material and methods}

The specimens were originally preserved in two large pieces of amber containing several other inclusions of arthropods as well as plant remains (see Table 1 for detailed list of syninclusions). Each piece was cut in smaller fragments for an optimal examination and description of the organic inclusions, using a scalpel blade as a microsaw. The resulting fragments were prepared using standard techniques for the preparation of fragile ambers (following Nascimbene and Silverstein, 2000). The fragments of amber were embedded in mineralogical-grade epoxy (Epotek-301) using a vacuum chamber. They were then cut and polished to remove excess material and provide a clear view. Observations were made using a 
stereomicroscope (Leica MZ12.5) and a compound microscope (Olympus CH30). Photographs were prepared using a Visionary Digital macrophotography station (a Canon EOS 5D DSLR camera equipped with a Canon MP-E-65 mm lens on a motorized stand). A series of pictures at various focal lengths were combined using Helicon Focus software in order to provide increased depth of field. Specimen illustrations were completed using a graphic tablet, Sketchbook Pro, and Adobe Photoshop software, in order to trace anatomical features directly from specimen photographs.

Measurements are given in millimetres and were obtained with an ocular micrometre. Abbreviation include: FRS meaning Fouras, France; ARC Archingeay, France; HL Head Length; HW: Head Width; MsL: Mesosomal Length; FWL: Forewing Length; MtL: Metasomal Length; PBL: Preserved Body Length. Notations include: first flagellomere and tarsomere are written FI and tarsomere I; second, FII and tarsomere II, etc.

All taxonomic acts established in the present work have been registered in ZooBank LSID (see below), together with the electronic publication, urn:Isid:zoobank.org:pub:BAAF35ECF6AC-4A7A-9931-4943DF3F03E6.

\section{Systematic palaeontology}

Suborder Apocrita Gerstaecker

Superfamily Chrysidoidea Latreille 
Family Chrysididae Latreille

Subfamily Cleptinae Latreille

Genus Sphaerocleptes gen. nov.

(urn:lsid:zoobank.org:act:5EB4CA1B-5D2B-49F9-A3DA-6B9BC25B4953)

Type species. Sphaerocleptes neraudeaui sp. nov., by monotypy and present designation.

Diagnosis. Spherical head, median sulcus extending from clypeus to median ocellus, antennae with elongate pedicel and scape and short compact flagellomeres. Mandibles bearing three apical teeth. Short pronotum and propodeum, broad mesoscutum. Forewing venation tubular, with no medial or submarginal cells, junction between two abscissae of $\mathrm{Cu}$ forms elbow.

Etymology. The genus name is a combination of the Latin word sphaero, meaning spherical, and the genus name Cleptes. The name is masculine.

Sphaerocleptes neraudeaui sp. nov.

(urn:1sid:zoobank.org:act:A12DD125-D5FE-443F-B86B-73E1992B84CE)

Figs. 2-3. 
Holotype. Specimen IGR.ARC-419.1 from lower Cenomanian amber of Archingeay (Charente-Maritime, southwestern France; lithological sub-unit A2sm1-2). Originally found in a cylindrical piece of brown, turbid amber containing six other arthropods (see Table 1 for detailed list of syninclusions), then cut into five smaller fragments for optimal examination and description. Specimen now in a small, flat piece of yellowish to brown amber rich in particulate inclusions, embedded in epoxy block measuring 12.5 x 6.4 x $2.4 \mathrm{~mm}$.

Diagnosis. As for genus (see above).

\section{Description:}

Head. Largely spherical in shape, hypognathous, with no evidence of occipital carina. Narrow median sulcus extending from clypeus, most of distance to median ocellus (reaching mid-length of compound eye). Ocelli are poorly preserved, apparently situated behind posterior margin of compound eye. Antennae with short compact flagellomeres. Scape elongate, subcylindrical, with slightly expanded apex extending above compound eye; pedicel elongate. Flagellomeres poorly visible due to orientation and bubble clouding in amber, but generally compact, with lengths half that of pedicel; apparently with eleven flagellomeres; ultimate flagellomere slightly longer than penultimate, with rounded apex; antennal setae short inclined and sparse. Maxillary palpus four-segmented, labial palpus three-segmented; mandibles short and thick, bearing three apical teeth on each side. 
Mesosoma. Pronotum preserved as translucent surface with little detail, short and gradually sloping anteriorly. Neck very short, short pronotum. Mesoscutum bulbous, with strongly impressed notauli throughout length; suture between mesoscutum and mesoscutellum straight (transverse) and narrow. Mesoscutellum with translucent preservation, apparently with smooth, convex surface, and slightly more than half length of mesoscutum. Metanotum broad and projecting posteriorly over propodeum, with low dorsal convexity; propodeum short (anteroposterior) with rounded posterolateral corners and steep posterior declivity. Petiole absent or very short.

Wing. Venation generally tubular. No medial or submarginal cell present; apical Rs tubular and curved, reaching anterior wing margin. Pterostigma present and R1 extending beyond it; R1 extends half-way to apex of Rs; Sc+R becoming thicker at junction with pterostigma. Basal segment of $\mathrm{M}$ concave toward wing apex, distal abscissa of $\mathrm{M}$ absent. Vein $\mathrm{Cu}$ reduced to just three abscissae; 1-Cu strongly curved toward posterior wing margin, whereas 2-Cu is slightly curved and reaching wing apex; junction between $\mathrm{Cu}$ abscissae forms elbow. Vein $\mathrm{A}$ disappearing distad 1cu-a. Hindwing: wing venation reduced to Sc+R, with no cells.

Legs. Abundant setae on legs, tarsomere I slightly shorter than combined length of II-IV in each tarsus, tarsomeres II-IV short. One fore-tibial spur very wide and curved; two mid-tibial spurs, one is shorter than other (half of length); two hind tibial spurs, one long and thick and other much shorter (approximately as long as one-sixth that of other tibial spur). Spicules visible along ventral margin apex of first tarsomere in hind legs and tarsomeres I-III in middle legs. Tarsal claws bearing perpendicular medial tooth. 
Metasoma. Metasoma wide and globular with a slight constriction at suture between first and second tergites.

Measurements. HL: 0.72; HW: 1.03; MsL: 1.59; FWL:2.33; MtL: 1.67; PBL: 3.97.

Etymology. The specific epithet is a patronym in honor of our colleague Didier Néraudeau who collected the amber pieces containing the three chrysidoid wasps described herein. His continuous effort to enrich the collection of Charentese amber greatly contributes to the knowledge of Cretaceous insects.

Family Bethylidae Haliday

Subfamily Bethylinae Haliday

Genus Nucifrangibulum gen. nov.

(urn:1sid:zoobank.org:act:28EBC07D-AF96-4884-572-D5A2D03C9DC6)

Type species. Nucifrangibulum carentonensis sp. nov., by monotypy and present designation.

Diagnosis. Head prognathous, mandibles broad and bearing four apical teeth, clypeus rounded. Ocelli at rear of head. Relatively long pronotum, metanotum with single row of foveae and propodeum sculptured dorsally. 
Etymology. The genus name comes from Latin and means 'nut-cracker' in reference to the broad and strong mandibles of the specimen.

Nucifrangibulum carentonensis sp. nov.

(urn:lsid:zoobank.org:act:7C9AC445-5633-4ED5-8299-83F2C5B158C6)

Fig. 4.

Holotype. Specimen IGR.FRS-7.28a, in lower Cenomanian amber from "Plage de la Vierge" (also named "plage du Bois Vert") at Fouras (Charente-Maritime, southwestern France; lithological sub-unit B2ms). Originally found in a piece of yellow, transparent amber containing 55 other arthropods (see Table 1 for detailed list of syninclusions), then cut into 35 fragments for optimal examination and descriptions; specimen now in a smaller fragment with another wasp from the family Scelionidae, the fragment embedded in epoxy block measuring $49.5 \times 26.2$ x 4.9 mm. Amber also with many debris, organic matter, wood fibers, and conifer twigs.

Diagnosis. As for genus (see above).

Description: Setation quite developed and observable on antennae, mandibles, clypeus, legs and metasoma. Mesosoma seems to be glabrous.

Head. Wide, prognathous without occipital carina, mandibles very broad and bearing four apical teeth, depression lateral to antennal toruli which are somewhat recessed with respect to clypeus 
and compound eye. Ocelli at back of head forming isosceles triangle, distance between lateral ocelli equivalent to about two ocellar diameters. Distance between median and lateral ocelli is approximately one ocellar diameter. Eyes egg-shaped, slightly more than half of head length. Antennae largely missing: just scape, pedicel and first flagellomere bearing thin setae are observable. Scape approximately double width of pedicel and slightly longer than pedicel. Characteristic clypeus is rounded and mound-shaped, with faint sulcus continuing dorsally, extending as far as torular depressions.

Mesosoma. Nearly no neck visible in dorsal view, long and relatively well-developed pronotum, with strong and rounded anterior slope. Short propleuron; mesoscutum transverse, with notauli; metanotum with row of foveae; propodeum sculptured (areolate-rugose type) and approximately as long as mesoscutum. Propodeum subrectangular in dorsal view, with posterolateral corners and strong posterior slope; lateral margin with setae.

\section{Wing. Not preserved.}

Legs. Middle and hind legs cut at tibia. All femora massive, broad. Femur and tibia with thick setae; all femora with rows of erect setae on ventral margin, and tibiae with field of inclined setae along entire ventral surface; protibia with apical collar of short spicules. Tibial spurs not preserved, except for single, robust, long spur on metatibia.

Metasoma. Petiole short and concealed. Torn, with only three first tergites preserved. TI - TIII increasing in width. TII and TIII with dark brown transverse band.

Measurements. HL: 0.54; HW: 0.74; MsL: 1.10; PBL: 1.28. 
Etymology. The specific epithet is derived from 'Carentonia', Latin name for the Charente river.

Subfamily indet.

Genus and species indet.

Fig. 5.

Material. Specimen IGR.FRS-7.34a, in lower Cenomanian amber from "Plage de la Vierge" (also named "plage du Bois Vert") at Fouras (Charente-Maritime, southwestern France; lithological sub-unit B2ms). Originally preserved in the same piece with $N$. carentonensis described above, as well as other syninclusions listed in Table 1; now in a smaller fragment (dimensions: $20.7 \times 18.5 \times 1.5 \mathrm{~mm}$ ) with a scelionid wasp and frass pellets. Amber yellow and very clear, platygastroid wasp and frass pellets present as syninclusions.

Description. Setation well-developed, with erect setae observable on mandibles, compound eyes, antennae, ventral parts of mesosoma and legs. Dorsal surface of specimen poorly preserved.

Head. Prognathous and rounded, with thin and long mandibles bearing four apical teeth on each side; teeth increasing in length from anterior to posterior. Clypeus prominent anteriorly, with triangular outline; toruli positioned close to clypeus and prominent, separated by narrow medial 
depression. Long prominent eyes occupying almost entire lateral surface of head. Ocelli poorly preserved but positioned near posterior margin of eyes; lateral ocellus separated from median ocellus by one diameter and from compound eye margin by three ocellar diameters. Antennae with eleven flagellomeres, pyriform pedicel, scape very long (about three times as long as pedicel) and wide. All flagellomeres showing numerous, circular sensillar patches: large patches approximately four times as wide as small patches. Last flagellomere with rounded apex. Flagellomeres FI-FIII decreasing in length, FIV-FVIII sub equal, FIX-FXI increasing in length, with FXI about 1.7 times length of FX. Fine occipital carina present.

Mesosoma. Mesosoma except pronotum not preserved. Pronotum preserved laterally, transparent, smooth, bulbous, without any grooves or setae apparent. Lateral propleuron smooth and slightly recessed, two spines on posterolateral margins.

Wing. Not preserved.

Legs. Only forelegs are preserved; one protibial spur bearing thin setae and divided into two branches at apex; protibial spur short, strongly curved and becoming subparallel to tibia apically. Tarsomere I-IV decreasing in length, tarsomere I longer than cumulative length of tarsomeres II-IV. Tarsomere V quite long, about as long as tarsomeres III and IV combined. First half of tarsomere I bearing setae forming a comb. Tarsal claw broad basally, curved and possibly bearing small medial tooth.

Metasoma. Not preserved.

Measurements. HL: 0.59; HW: 0.74; MsL: 1.10; PBL: 1.28. 


\section{Discussion}

Sphaerocleptes neraudeaui matches well with the diagnosis of the Cleptinae despite some differences in characters. The occipital carina seems to be absent, as do the parapsidal lines, and the grooves or pits of the pronotum are not visible. However, these apparent character differences should be interpreted with caution: the metasoma is not very well-preserved and is dark, while the pronotum is very pale, with nearly transparent preservation. Some of these features may be present but not observable. One of the most important characteristic features of the Cleptinae, the medial carina dorsal to the clypeus is present, and it is followed dorsally by a fine medial sulcus. Furthermore, four segments are visible within the metasoma. Consequently, in all likelihood, S. neraudeaui belongs to the subfamily Cleptinae.

Among the cleptine genera, $S$. neraudeaui shares common features with the fossil genus Protamisega and the extant genus Cleptes. The wing venation is quite similar to that of Protamisega. However, unlike Protamisega, the marginal cell is absent, and there is no visible apical abscissa of M. In addition, the propodeum has a steep posterior slope, the notauli are deeply impressed, and the scape of the antennae is very long. Like Cleptes, the new species has tarsal claws bearing a small, perpendicular, medial tooth, eyes that are quite small and follow the head contours, and short mandibles that are quite robust with three teeth. The new taxa has a short pronotum and doesn't seem to present particular details such as a furrow. On the contrary, Hypocleptes and Procleptes have a rather long pronotum, with a deep transverse furrow in Hypocleptes. Also, contrary to S. neraudeaui, these two taxa have simple claws. In addition, Procleptes shows a propodeum with acute process on each side; this structure is absent in Sphaerocleptes. Nonetheless, Hypocleptes and Sphaerocleptes have also a common feature: the presence of a mesoscutum with strong notauli. Sphaerocleptes differs clearly from Hypocleptes 
and Procleptes by his general morphology and especially by the rounded head and the wide and globular metasoma (the three apical segments, in Hypocleptes and Procleptes, are in the form of a tube) as well as the forewing venation. Besides, the new genus differs from all other taxa of Cleptinae previously described by a unique forewing venation: the vein $\mathrm{Rs}+\mathrm{M}$ is absent and $\mathrm{M}$ is combined with tubular $\mathrm{Cu}$ almost reaching the wing outer margin. The new species also presents an unusual abundance of pale setae on the legs. The mosaic of features presented by $S$. neraudeaui could not be accommodated within genera that share the greatest number of similarities (Protamisega or Cleptes), or any other Mesozoic genus (Hypocleptes or Procleptes), which led us to define a new genus and species.

Nucifrangibulum carentonensis is partial: most of the antennae are missing as well as the wings, and the metasoma is torn. However, based on some features of the propodeum and the metasoma, the specimen is placed confidently within the subfamily Bethylinae. Features that support placement within Bethylinae include the rounded clypeus with a fine carina continuing dorsally, and the absence of occipital carina. The new taxon has a unique propodeum: large, subrectangular, with an ornamentation (areolate-rugose type) and without carinae. Like Prosierola the new genus has a mandible with four apical teeth and large glabrous eyes. But the new genus can be easily differentiated by a few features, such as the presence of well-marked notauli (usually absent or weak in Prosierola), a scutellum without anterior pits (present in Prosierola), and the propodeal disc without any pits (presence of a pair of rounded or elliptical pits in Prosierola). Lytopsenella also exhibits a mandible with four apical teeth, but differs from the new genus by having hirsute eyes, the presences of notauli and parapsidal lines (notauli visible only in Nucifrangibulum), and the absence of a petiole. The genera Sierola and Afrobethylus, differ by the absence of notauli (present in the new genus). The propodeum of the 
new genus, without any particular carinae, allows it to be differentiated from the genera Odontepyris and Eupsenella (having a median longitudinal carina on the propodeum). The genus Bethylus is characterized by a propodeum without carinae, like the new genus, but also by the absence of a frontal streak (structure present in the new genus). Thus, the new taxon cannot be assigned to any of the genera previously described. Consequently, this is the first Cretaceous record of the Bethylinae.

The other specimen from Fouras, specimen IGR.FRS-7.34a, is very partial: too little of the specimen is present to assess diagnostic characters for the subfamilies, which rely strongly on characteristics of the propodeum, venation, and other body regions that are not preserved. Consequently, the new specimen is left in open nomenclature as indeterminate. However, it shows a few special features that may be retrieved in more complete specimens from the same deposits: the protibial spur is divided in two branches at the apex, abundant setation is present on numerous body regions, the basitarsus has a well-developed basal comb of setae, and the antennal flagellomeres bear two types of sensillar patches. Without more complete material, we can only identify this specimen as a member of the family Bethylidae, but we cannot precise his taxonomic affinities. Placement within the Bethylidae can be confirmed on the basis of the long intergenal suture, the number of flagellomeres (11), the head being prognathous, the presence of a transverse and recessed prosternum, and the propleuron being concealed by an anterior pronotal flange.

\section{Conclusion}


The study of three new specimens from French Charentese ambers led to the definition of two new genera and two new species. Due to the partial preservation of one of the specimens, the genus and species could not be defined confidently, and thus they are left in open nomenclature as indeterminate. Two families, Chrysidoidea and Bethylidae, and two subfamilies, Cleptinae and Bethylinae, were identified. These findings represent the first records of these subfamilies in Charentese amber, and on a larger scale, the first record for the subfamily Bethylinae in the Mesozoic. They allow us to fill in a little more of the otherwise scarce Cretaceous record for the Chrysidoidea and support the idea that the continued study of Charentese amber should increase the discovery of new relevant material in the future.

\section{Acknowledgements}

We are grateful to Prof. Didier Néraudeau (University of Rennes 1) for providing access to the amber pieces containing the specimens. We are also grateful to two anonymous reviewers and Dr. Eduardo Koutsoukos for constructive comments on this work. Support was provided by the Natural Sciences and Engineering Research Council of Canada (grant 2015-00681), by CNRS-INSU grant Interrvie NOVAMBRE 2 (to V.P.), and by the French government scholarship "Bourse sur critères sociaux" (to P.C.). This work is part of the MSc thesis of Pierre Cockx, supported by NSERC Discovery Grant held by Ryan McKellar, and supervised by Vincent Perrichot. 


\section{References}

Alencar, I.D.C.C., Azevedo, C.O., 2013. Reclassification of Epyrini (Hymenoptera: Bethylidae): a tribal approach with comments on their genera. Systematics Entomology 38, 45-80.

Azevedo, C.O., Azar, D., 2012. A new fossil subfamily of Bethylidae (Hymenoptera) from the Early Cretaceous Lebanese amber and its phylogenetic position. Zoologia 29, 210-218.

Barbosa, D.N., Perkovsky, E.E., Azevedo, C.O., 2013. Two new species of Laelius Ashmead (Hymenoptera, Bethylidae) from Upper Eocene Rovno amber. Neues Jahrbuch für Geologie und Paläontologie 267 (1), 67-73.

Brothers, D.J., Carpenter, J.M, 1993. Phylogeny of Aculeata: Chrysidoidea and Vespoidea (Hymenoptera). Journal of Hymenoptera Research 2, 227-304.

Brues, C.T., 1933. Phylogeny of Aculeata: Chrysidoidea and Vespoidea (Hymenoptera), Part 1. Bernstein Forschungen 3, 4-178. 
Carr, M., Young, J.P.W., Mayhew, P.J, 2010. Phylogeny of bethylid wasps (Hymenoptera:

Bethylidae) inferred from 28S and 16S rRNA genes. Insect Systematics and Evolution 41, 5573.

Cockerell, T.D.A., 1907. Some fossil arthropods from Florissant, Colorado. Bulletin of the American Museum of Natural History 23, 605-616.

Cockerell, T.D.A., 1917a. Arthropods in Burmese amber. American Journal of Science 44 (4), $360-368$.

Cockerell, T.D.A., 1917b. Arthropods in Burmese amber. Psyche 24, 40-44.

De Ploëg, G., Nel, A., 2004. A new bethylid wasp from the Lowermost Eocene amber of France (Hymenoptera: Bethylidae: Bethylinae). Geologica Acta 2, 75-82.

Engel, M.S., 2006. A new cuckoo wasp of the genus Ceratochrysis in amber from the Dominican Republic (Hymenoptera: Chrysididae). Polski Pismo Entomologiczne 75, 499-504. 
Engel, M.S., Ortega-Blanco, J., Azevedo, C.O., 2016. A new bethylid wasp in Lebanese Early Cretaceous amber (Hymenoptera: Chrysidoidea), with comments on other Mesozoic taxa. American Museum Novitates 3855, 1-14.

Evans, H.E., 1969. Three new Cretaceous aculeate wasps (Hymenoptera). Psyche 76, 251-261.

Evans, H.E., 1973. Cretaceous aculeate wasps from Taimyr, Siberia (Hymenoptera). Psyche 80, $166-178$.

Finnamore, A.T., Brothers D.J., 1993. Superfamily Chrysidoidea. In: Goulet, H., and Huber, J.T. (eds.), Hymenoptera of the world: an identification guide to families, Research Branch Agriculture Canada Publication, Ottawa, 130-160.

Förster, B., 1891. Die Insekten des "Plattigen Steinmergels" von Brunstatt. Abhandlungen zur Geologischen Spezialkarte von Elsass-Lothringen 3, 333-594.

Gomez, B., Coiffard, C., Dépré, E., Daviero-Gomez, V., Néraudeau, D., 2008. Diversity and histology of a plant litter bed from the Cenomanian of Archingeay-Les Nouillers (southwestern France). Comptes Rendus Palevol 7, 135-144. 
Grimaldi, D.A., Nascimbene P.C., 2010. Raritan (New Jersey) amber. In: Penney, D. (ed), Biodiversity of fossils in amber from the major world deposits. Siri Scientific Press, Manchester, $167-191$.

Hong, Y.-C., 2002. Amber insects of China. Science and Technic Publishing House, Beijing. (in Chinese)

Huber, J.T. 2009. Biodiversity of Hymenoptera. In: Foottit, R., and Adler, P. (eds.), Insect Biodiversity: Science and Society, Wiley-Blackwell, Oxford, 303-323.

Kimsey, L.S., Bohart, R.M., 1990. The Chrysidid Wasps of the World. Oxford Science Publications, New York, NY, 652 pp.

Krombrein, K.V., 1986. Three Cuckoo Wasps From Siberian and Baltic Amber (Hymenoptera: Chrysididae: Amiseginae and Elampinae). Proceedings of the Entomological Society of Washington 88 (4), 740-747. 
Martínez-Delclòs, X., Arillo, A., Ortuño, V., Peñalver, E., 1999. El ámbar del Cretácico Inferior de Peñacerrada (Álava, España). Temas Geológico-Mineros ITGE 26, 13-17.

McKellar, R.C., Engel, M.S., 2014. New bethylid and chrysidid wasps (Hymenoptera:

Chrysidoidea) from Canadian Late Cretaceous amber. Paläontologische Zeitschrift 88 (4), $433-451$.

Nascimbene, P., Silverstein, H., 2000. The preparation of fragile Cretaceous ambers for conservation and study of organismal inclusions. In: Grimaldi, D.A. (Ed.), Studies on Fossils in Amber, with Particular Reference to the Cretaceous of New Jersey. Backuys Publishers, Leiden, The Netherlands, 93-102.

Néraudeau, D., Allain, R., Perrichot, V., Videt, B., De Broin, F.D.L., Guillocheau, F., Philippe, M., Rage, J.-C., Vullo, R., 2003. Découverte d'un dépôt paralique à bois fossiles, ambre insectifère et restes d'Iguanodontidae (Dinosauria, Ornithopoda) dans le Cénomanien inférieur de Fouras (Charente-Maritime, sud-ouest de la France). Comptes Rendus Palevol 2, 221-230.

Néraudeau, D., Perrichot, V., Dejax, J., Masure, M., Nel, A., Philippe, M., Moreau, P., Guillocheau, F., Guyot, T., 2002. Un nouveau gisement à ambre insectifère et à végétaux (Albien terminal probable) : Archingeay (Charente-Maritime, France). Geobios 35, 233-240. 
Ortega-Blanco, J., Engel, M.S., 2013. Bethylidae from Early Cretaceous Spanish amber (Hymenoptera: Chrysidoidea). Journal of the Kansas Entomological Society 86, 264-276.

Peñalver, E., Delclòs, X., 2010. Spanish amber. In: Penney, D. (ed), Biodiversity of Fossils in Amber from the Major World Deposits. Siri Scientific Press, Manchester, 236-269.

Perkovsky, E.E., Rasnitsyn A.P., 2013. First records of Scolebythidae and Chrysididae (Hymenoptera, Chrysidoidea) in Rovno amber. Vestnik Zoologii 47, 113-118.

Perrichot, V., Nel, A., 2008. Eocene bethylid wasps from French amber (Hymenoptera: Bethylidae). Neues Jahrbuch für Geologie und Paläontologie Abhandlungen 248, 91-101.

Perrichot, V., Néraudeau, D., Tafforeau, P., 2010. Charentese amber. In: Penney, D. (ed.), Biodiversity of Fossils in Amber from the Major World Deposits. Siri Scientific Press, Manchester, 192-207.

Poinar, G.O.Jr., Milki, R., 2001. Lebanese amber, the oldest ecosystem in fossilized resin. Oregon State University Press, Corvalis, Oregon, 96 pp. 
Ramos, M.R., Perkovsky, E.E., Rasnitsyn, A.P., Azevedo, C.O., 2014. Revision of Bethylinae fossils (Hymenoptera: Bethylidae) from Baltic, Rovno and Oise amber, with comments on the Tertiary fauna of the subfamily. Neues Jahrbuch für Geologie und Paläontologie 271 (2), $203-228$.

Rasnitsyn, A.P., 1990. Hymenoptera. Vespida. In: Rasnitsyn, A.P. (Ed.). Late Mesozoic insects of Eastern Transbaikalia. Trudy Paleontologicheskogo Instituta Akademii Nauk SSSR 239, 177205. (in Russian).

Rasnitsyn, A.P, Bashkuev, A.S., Kopylov, D.S., Lukashevich, E.D., Ponomarenko, A.G., Popov, Yu.A., Rasnitsyn, D.A., Ryzhkova, O.V, Sidorchuk, E.A., Sukatsheva, I.D., Vorontsov, D.D, 2016. Sequence and scale of changes in the terrestrial biota during the Cretaceous (based on materials from fossil resins). Cretaceous Research 61, 234-255.

Ross, A., Mellish, C., York, P., Crighton, B., 2010. Burmese amber. In: Penney, D. (Ed.), Biodiversity of Fossils in Amber from the Major World Deposits. Siri Scientific Press, Manchester, 208-235.

Sorg, M. 1988. Zur Phylogenie und Systematik der Bethylidae (Insecta: Hymenoptera: Chrysidoidea). Sonderveröffentlichungen des Geologischen Instituts der Universität zu Köln 63, $1-146$. 
Terayama, M. 2004. Descriptions of new taxa and distribution records of the family Bethylidae (Insecta, Hymenoptera) II. Subfamily Bethylinae and fossil taxa. Academic Reports, Faculty of Engineering, Tokyo Polytechnic University 27, 39-52. 


\section{Figure captions.}

Fig. 1. Geographical and geological settings of the Cretaceous Charentese amber deposits considered in the present study. A. Location of the sites. B. Regional stratigraphic section with indication of the two amber levels yielding the fossil chrysidoid wasps (numbers of sites correlate with A).

Fig. 2. Photomicrographs of Sphaerocleptes neraudeaui gen. et sp. nov. from Charentese upper Cretaceous amber. Dorsal (A) and ventral (B) views of the holotype (ARC 419.1). Scale bar = 1 $\mathrm{mm}$.

Fig. 3. Sphaerocleptes neraudeaui gen. et sp. nov., holotype (ARC-419.1), dorsal (A) and ventral (B) views habitus. Scale bar $=1 \mathrm{~mm}$.

Fig. 4. Photomicrograph (A) and habitus (B) in dorsal view of Nucifrangibulum carentonensis gen. et sp. nov., holotype (FRS-7.34) from Charentese upper Cretaceous amber. Scale bar $=1$ $\mathrm{mm}$.

Fig. 5. Photomicrographs of the specimen IGR.FRS-7.34a from Charentese upper Cretaceous amber. Dorsal (A) and ventral (B, D) views, and details of the foreleg (C) of the holotype (FRS7.34). A, B, D: scale bar $=1 \mathrm{~mm}$; C: scale bar $=0.25 \mathrm{~mm}$. 
Table 1. List of syninclusions in Charentese amber pieces discussed herein (*wasps described in the present paper).

\begin{tabular}{|c|c|c|c|}
\hline Amber piece & $\begin{array}{l}\text { Class } \\
\text { Order }\end{array}$ & Suborder/Family & \\
\hline \multirow{5}{*}{ IGR.ARC-419 } & \multicolumn{3}{|l|}{ Insecta } \\
\hline & Diptera & Ceratopogonidae & 1 \\
\hline & Hymenoptera & Chrysididae: Cleptinae* & 1 \\
\hline & & Maimetshidae & 3 \\
\hline & & Scelionidae & 2 \\
\hline \multirow{27}{*}{ IGR.FRS-7 } & Plantae & & \\
\hline & Pinales & indet. & 3 \\
\hline & Diplopoda & & \\
\hline & Polyxenida & Polyxenidae & 1 \\
\hline & Arachnida & & \\
\hline & Acari & Oribatida, Brachypilina & 8 \\
\hline & & Parasitengona & 2 \\
\hline & & Anistidae & 1 \\
\hline & & indet. & 7 \\
\hline & Araneae & indet. & 1 \\
\hline & Pseudoscorpiones & Cheiridioidea & 2 \\
\hline & Entognatha & & \\
\hline & Collembola & indet. & 6 \\
\hline & Insecta & & \\
\hline & Coleoptera & Cleridae & 1 \\
\hline & & Melyridae & 1 \\
\hline & & indet. & 3 \\
\hline & Diptera & $\begin{array}{l}\text { Phoridae } \\
\text { indet. }\end{array}$ & 1 \\
\hline & Hemiptera & Fulgoromorpha & 3 \\
\hline & & Formicidae & 2 \\
\hline & & Megaspilidae & 1 \\
\hline & & Mymaridae & 1 \\
\hline & & Scelionidae & 8 \\
\hline & & Sclerogibbidae & 1 \\
\hline & Lepidoptera & indet, (scales) & 1 \\
\hline & Indet. (larvae) & 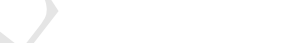 & 1 \\
\hline & Arthropoda & indet. & 1 \\
\hline
\end{tabular}




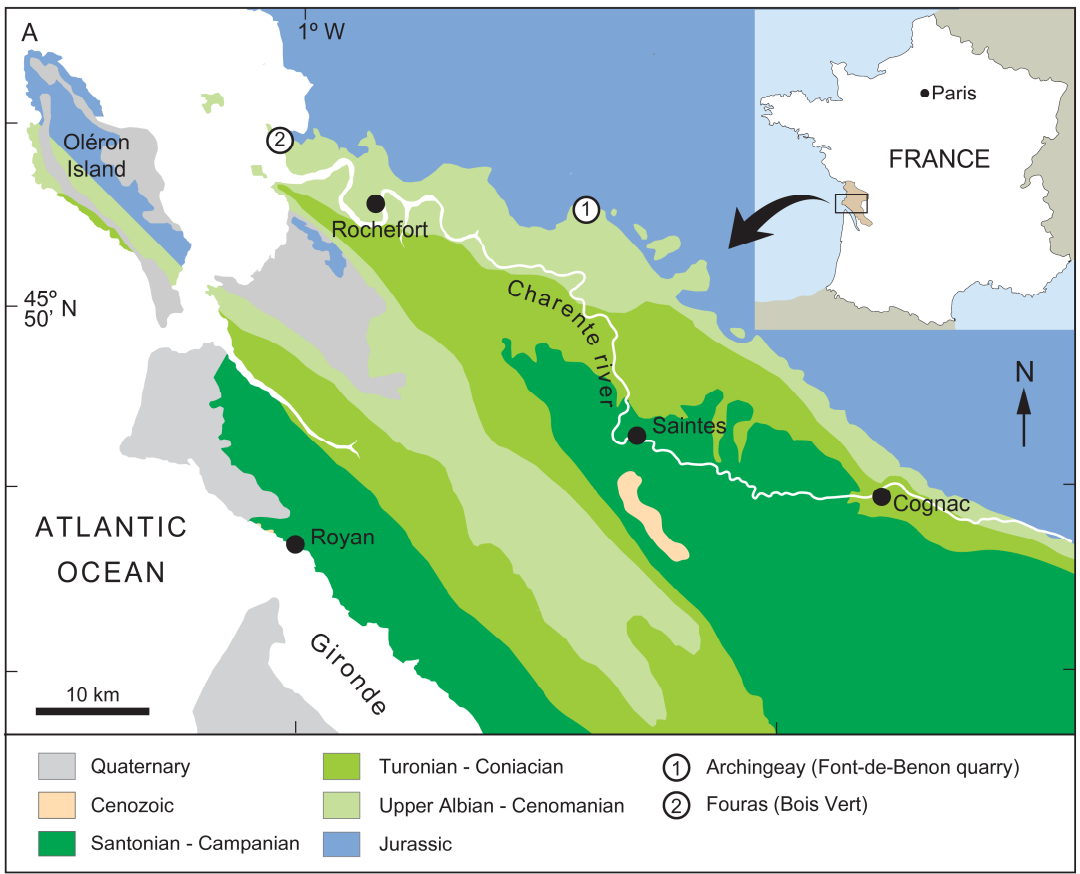

B

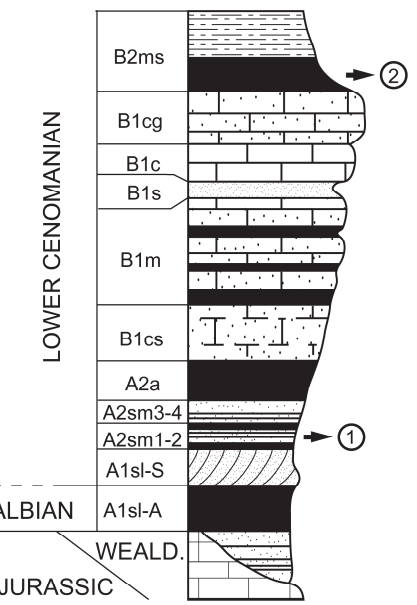



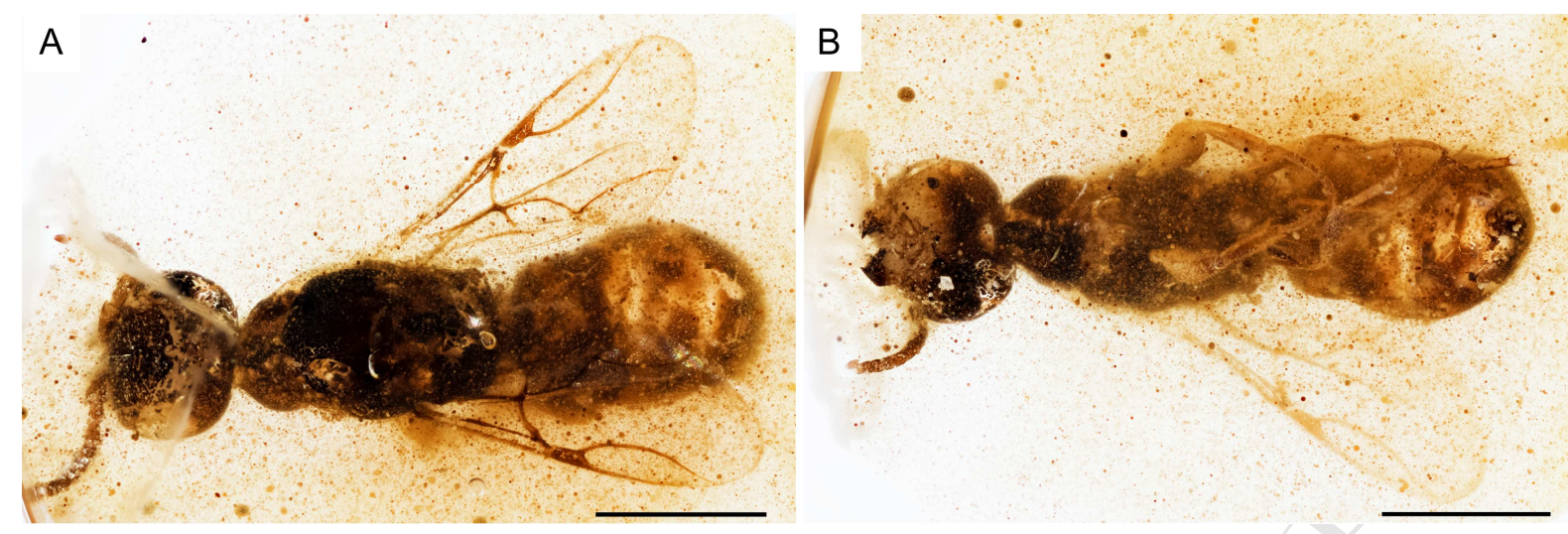


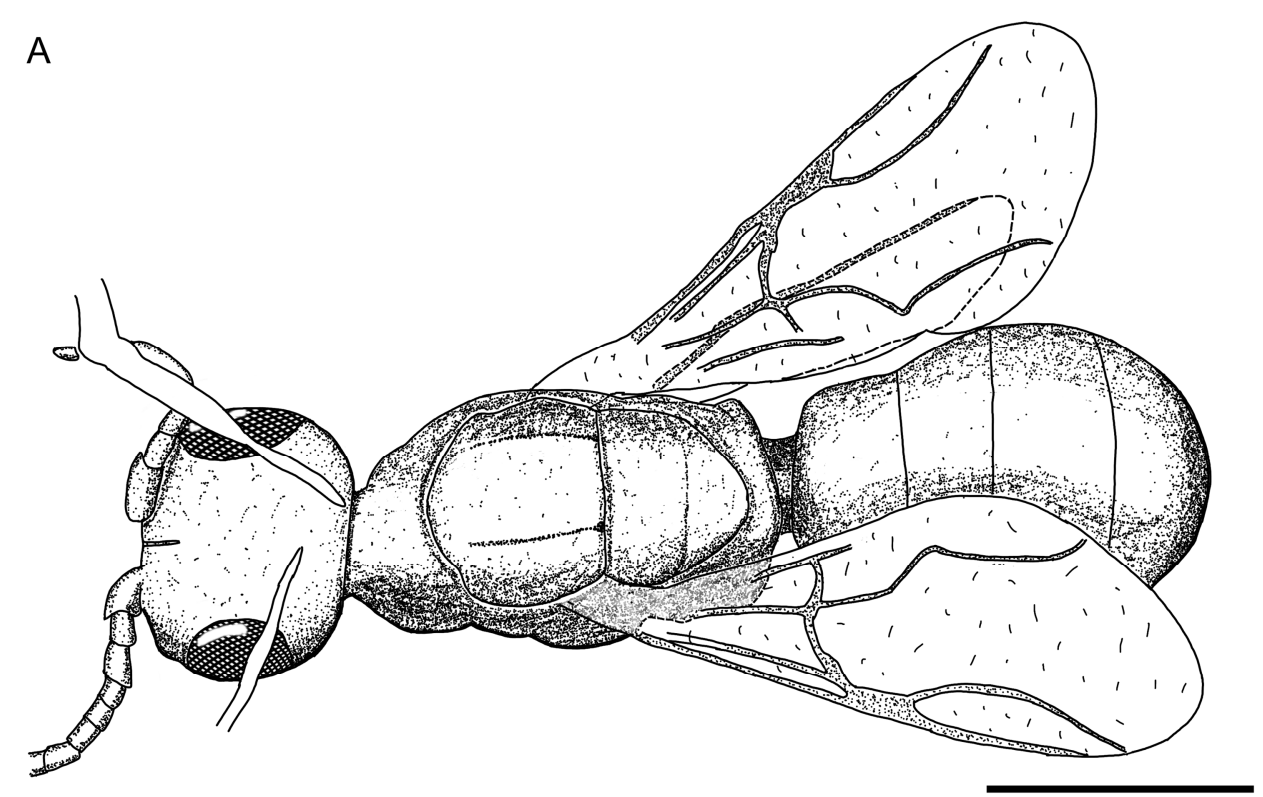

B

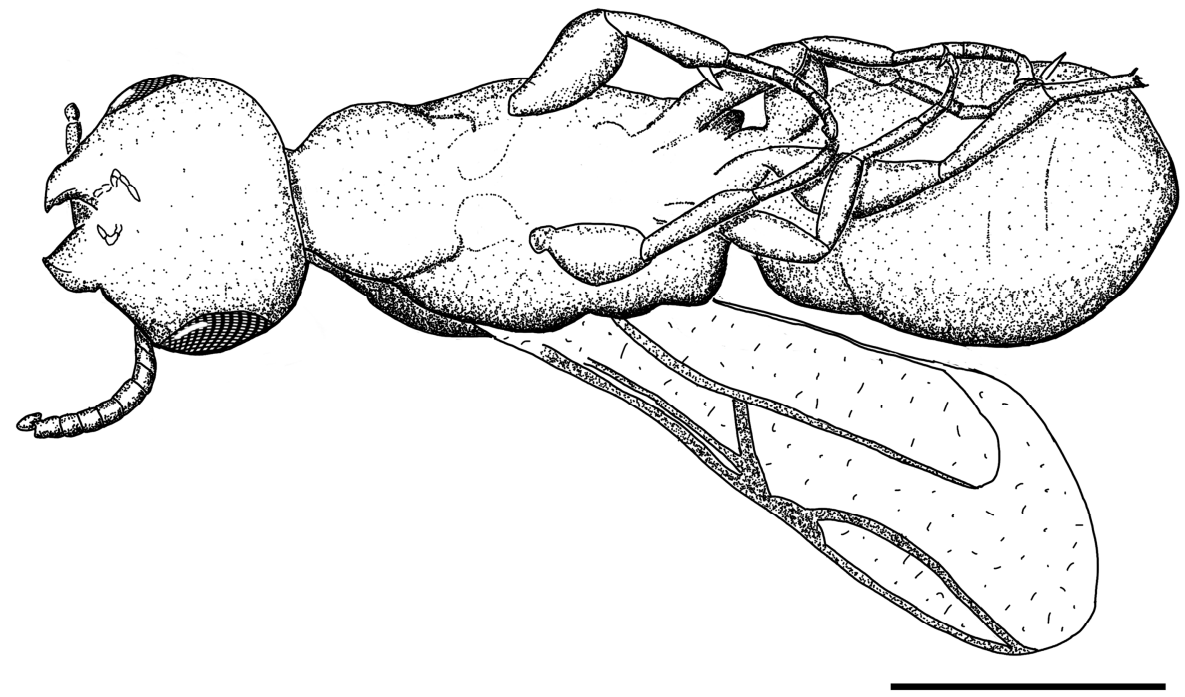




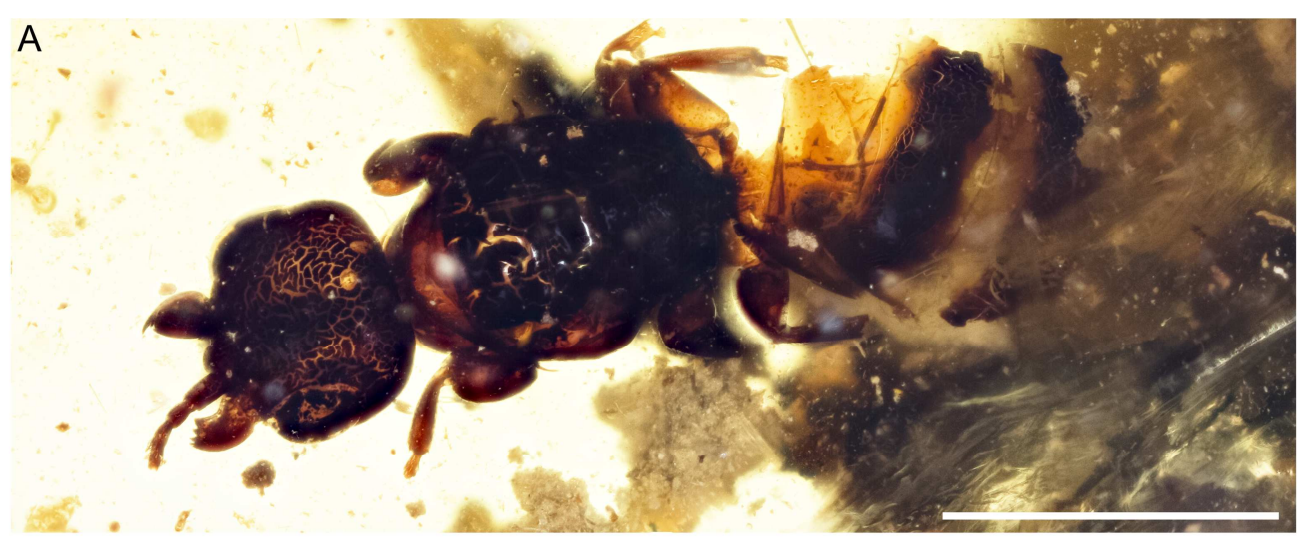

B

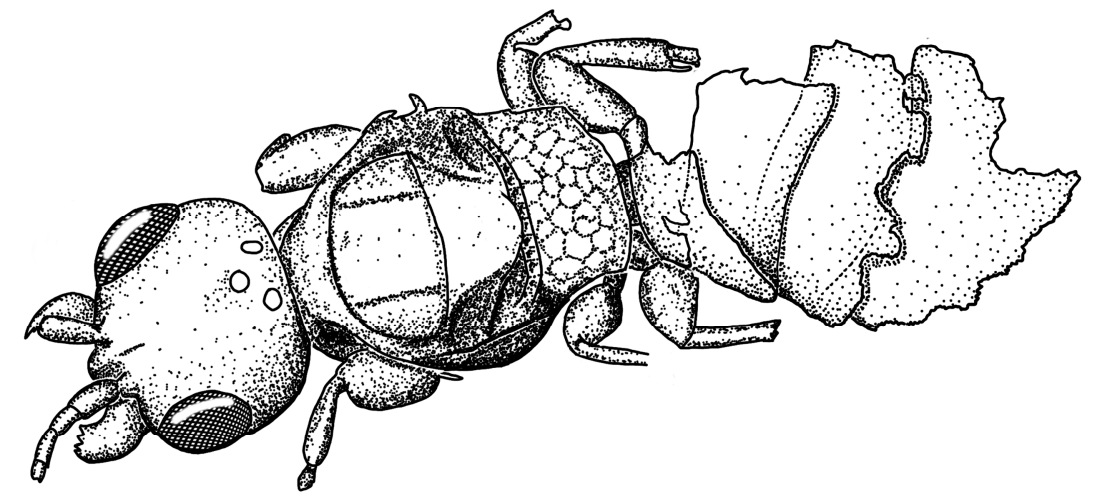




\section{ACCEPTED MANUSCRIPT}
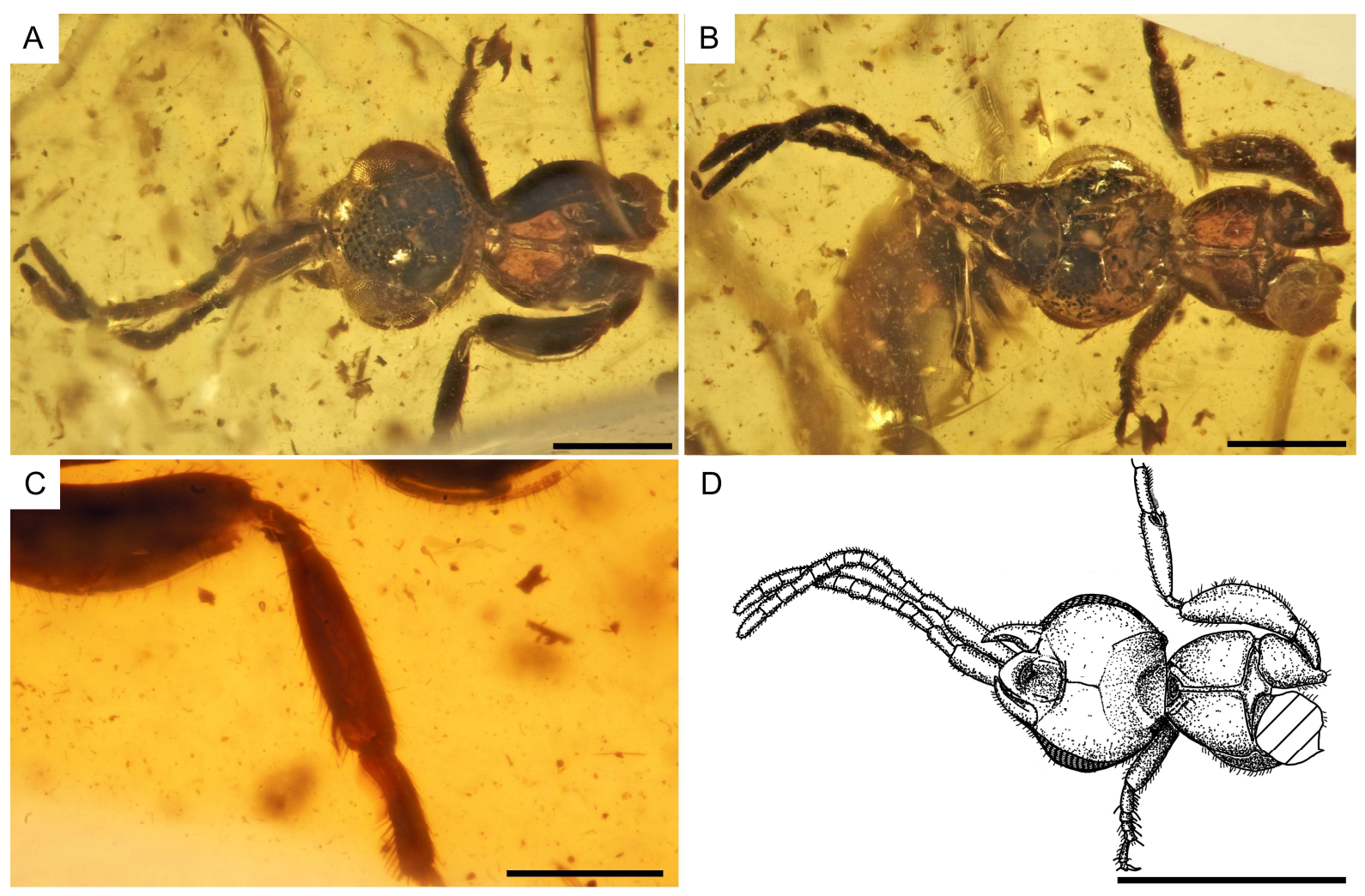

D

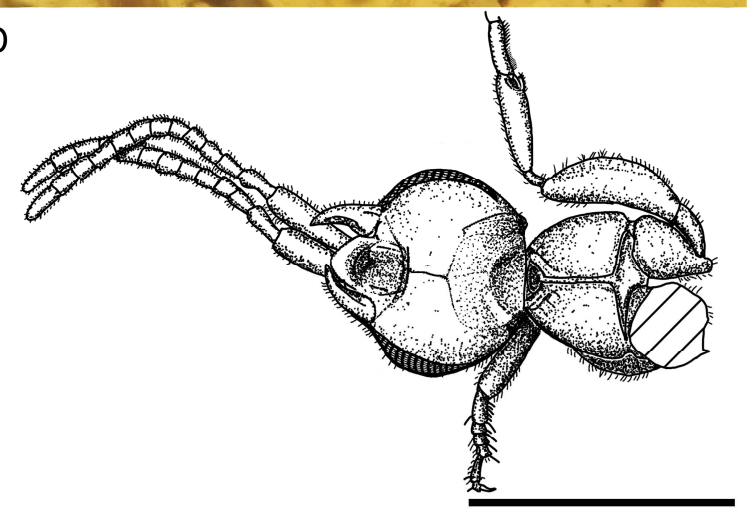

